\section{Zvonko Maković}

predsjednik Društva povjesničara umjetnosti Hrvatske

DOI:

$10.17685 /$ Peristil.61.22

\section{Vlastimir Kusik (1953.-2018.)}

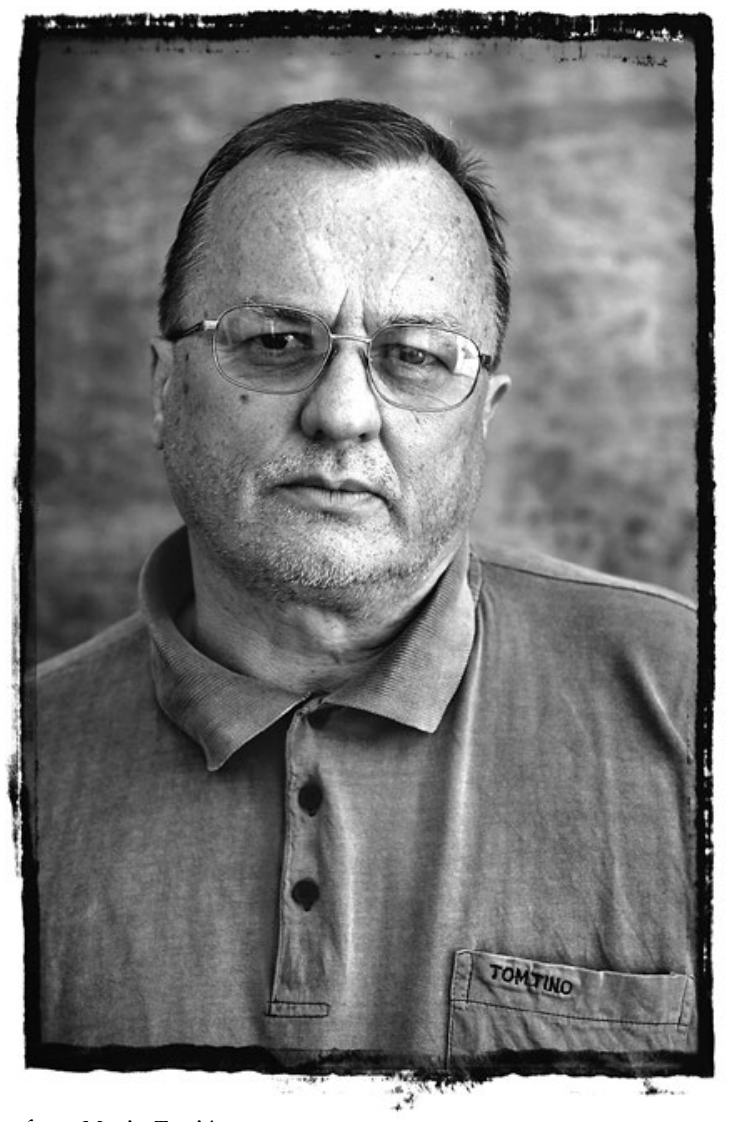

foto: Marin Topić

U veljači 2018. godine Vlastimir Kusik napustio je svoje radno mjesto u Muzeju likovnih umjetnosti u Osijeku otišavši u zasluženu mirovinu. U istoj je ustanovi radio od 1981. stječući zvanje kustosa (1984.), višega kustosa (1994.) te muzejskog savjetnika (2004.), a prije nego što je ušao u ustanovu s kojom se tako često poistovjećuje njegov rad, bio je od 1977. do 1981. zaposlen u Regionalnom zavodu za zaštitu spomenika u Osijeku. Diplomirao je 1976. na Filozofskome fakultetu u Zagrebu studij povijesti umjetnosti i arheologije, a osnovnu školu i gimnaziju završio u rodnome Osijeku. Počeo je objavljivati likovne kritike još tijekom studentskih dana, stjecao dragocjena poznanstva s umjetnicima rad kojih će pratiti do kraja života. Bile bi to osnovne činjenice koje se tiču stručne biografije ovoga istaknutog povjesničara umjetnosti, kritičara, kustosa, autora mnogih izložaba i nadasve zaslužnog kulturnog djelatnika. Osim mnogih kataloga u kojima su tiskani njegovi predgovori, eseji, veće studije, ostala je iza njega i knjiga neobičnog naslova - Adresa - koji bolje pojašnjava podnaslov: Eseji, kritike, kolumne i ostalo. Nakladnik je knjige Matica hrvatska, Ogranak Osijek, a izašla je 2007. Baš ta knjiga najbolje svjedoči kako Kusikov rad, tako i njegov profil intelektualca širokoga znanja koji slobodno povezuje na prvi pogled ne osobito bliske teme. I to povezivanje, taj Mélanges otkriva nam maštovitost i duhovno bogatstvo autora. Kroz tekstove sabrane u ovoj knjizi na fini se način provlači 
afirmacija lokalnih posebnosti, točnije ljubav prema rodnome gradu koji se ne promatra izolirano, nego se u njemu prepoznaju silnice koje će Osijek činiti kozmopolitskim i otvorenim. Autor nas uvodi u sve slojeve grada koji nije samo zbroj ulica, trgova i lijepih parkova, pa ni stanovnika koji su ga stoljećima oblikovali, nego sve to zajedno. Kusik čitatelja upoznaje s umjetnicima koji su u ovome gradu boravili i obogaćivali ga, a često su ostajali nepoznati, baš kao i onima koji su, napustivši Osijek, afirmaciju stekli drugdje, ali se uvijek sjećali svojih korijena.

Niti jedan drugi kritičar, kustos, muzealac, nije na tako jednostavan način uspio afirmirati lokalni štih s univerzalnim, a da u tome ne izbija provincijalno pretjerivanje. Kusik je bio taj koji je u Osijek dovodio najveće umjetnike, recentne umjetničke pojave i implementirao ih u svoju sredinu za koju je bio silno vezan i iskreno je volio. Nije bio uzak, nego je s podjednakom pozornošću razmatrao i likovnu baštinu, od one starijih razdoblja do suvremene i to povezivao s kulturom u najširem smislu riječi - od rock i pop - kulture, do kulture svakodnevice, kulture koja je nastajala u kavanama i na ulicama Osijeka. Nijedan drugi muzealac nije Osijek na tako nenametljiv način afirmirao i vidio u njemu vrijednosti koje su taj grad činile i čine posebnim. Kusik je to uspijevao i stoga što je svoj grad vidio kao relevantnu pozornicu na kojoj i najveća imena suvremene umjetnosti mogu naći dobre rezonancije. Ističući svoj grad, svoju sredinu Vlastimir Kusik nije nikada upadao u lokalizam, jer mu je svaki lokalizam bio beskrajno stran.

Iza sebe Kusik je ostavio brojne izložbe klasika hrvatske umjetničke scene, tako Marina Tartaglie, Julija Knifera, Đure Sedera, Ivana Kožarića, Marijana Jevšovara pa do Damira Sokića, Nine Ivančić, Slavomira Drinkovića, Edite Schubert, Lovre Artukovića i mnogih, mnogih drugih. Pored ovih umjetnika upravo je Kusikova zasluga da je nekolicinu umjetnika iz vlastite sredine prvi prepoznao i uspio nametnuti kao relevantne protagoniste hrvatske suvremene umjetnosti, od Ivana Faktora, Bore Ivandića, Davora Vrankića, Marija Čaušića do nekolicine drugih. Umjetnost nikada nije promatrao s distance, nego ju je živio i njoj je pripadao. Iza sebe je ostavio niz problemskih i tematskih izložaba koje su instituciju u kojoj je radio, negdašnju Galeriju, danas Muzej likovnih umjetnosti, uzdigao na poziciju vrijednih nacionalnih likovnih institucija. Među takvim izložbama izdvojio bih Gorgona i poslije, Primarno i analitičko slikarstvo, Tübingenski ciklus Julija Knifera, Izložba mađarske avangarde: Osmorica i Aktivisti, Umjetnička skupina IRWIN, Nova hrvatska umjetnosti, izmedu centra i periferije i mnoge, mnoge druge.

Muzej likovnih umjetnosti Osijek Kusikovim je odlaskom u mirovinu nedvojbeno izgubio svog vrijednoga djelatnika, no pomoć, upravo mentorski rad s mlađim kolegicama i kolegama, bio je od iznimne važnosti. Pomagao im je dok je bio u ustanovi, baš kao i nakon oslaska u mirovinu, a planovi su postojali da se takva pomoć nastavlja i da duh ovoga kustosa i kritičara ostane što prisutniji u muzeju i gradu. Nažalost, vrijeme od odlaska u mirovinu (8. veljače 2018.) i definitivnoga odlaska (27. svibnja 2018.) bilo je isuviše kratko da bi se započeto i dogovoreno moglo nastaviti. Tragičan udes trajno je ovoga duhom, kulturom i znanjem bogatoga pregaoca fizički odstranio iz sredine kojoj je duboko pripadao. Utjeha može jedino biti da su doprinosi koje je Vlastimir Kusik ostavio svojem gradu, Slavoniji i Hrvatskoj, trajni i prepoznatljivi. Na taj se način njegova nazočnost nastavlja i dobiva jasne obrise. 